\title{
Spatial Distribution of Uca sindensis (Crustacea, Ocypodidae) along the coast of Pakistan
}

\author{
Noor Us Saher ${ }^{1}$ and Naureen Aziz Qureshi ${ }^{2}$ \\ 1. Centre of Excellence in Marine Biology, University of Karachi, Karachi 75270, \\ Pakistan \\ 2. Department of Wildlife and Fisheries Government College University, Faisalabad \\ Allama Iqbal Road, 38000, Faisalabad \\ Corresponding author: E. Mail: noorusaher@yahoo.com
}

\section{ABSTRACT}

Spatial distribution of Uca sindensis was studied along the coast of Pakistan. The density, size distribution, population structure, sex ratio and handedness were investigated. $U$. sindensis crabs were collected through quadrate $\left(0.5 \mathrm{~m}^{2}\right.$ quadrates were placed during low tide periods) and transect (low tide mark to high tide mark) method from nine different sites along the coast. Results indicated that the substratum properties (organic content, size, and heterogeneity) were of primarily importance for the distribution of $U$. sindensis. The spatial variation was observed in the density distribution and was ranged from 4 to $48 \mathrm{~m}^{-2}$. The overall sex ratio was differed significantly from the expected $1: 1\left(\chi^{2}=22.4 ; \mathrm{P}=0.004\right)$. The sizes of the male and female crabs were significantly different at all studied sites. The carapace $(\mathrm{CW})$ of males ranged from 8.3 to $17.3 \mathrm{~mm}$ and of females from 6.2 to $14.4 \mathrm{~mm}$ indicating sexual dimorphism. The occurrence of dextral and sinistral males was overall in the $1: 1$ ratio.

Key words: $U$. sindensis, Pakistan, Spatial distribution, percent organic, Handedness

\section{INTRODUCTION}

Fiddler crabs are ubiquitous brachyuran element in the muddy, muddy-sand or sandy-mud intertidal zone of mud-sandy sediments in estuarine and sheltered areas throughout tropical and subtropical regions of the world (Nobbs and Mc Guiness, 1999; Costa and Negeiros-Fransozo, 2002; Johnson, 2003; Nobbs, 2003; César et al., 2005; Ribeiro et al., 2005) and form the largest component of macro faunal biomass of inter-tidal mangrove ecosystem (Montague, 1980; Barnes, 2010). They are mostly small, highly social, and conspicuous inhabitants that play important functional roles in coastal ecosystems. The existence and distribution of fiddler crabs are affected by a combination of numerous environmental parameters, such as salinity, temperature, tidal exposure, sediment characteristics, availability of nutrients, availability of oxygen, interspecific or intraspecific competition, and hence a large amount of ecological work exists on the group (Costa and Negreiros Fransozo, 2001; 2002; Colpo and Negrirose Fransozo, 2004; Litulo, 2005; Mokhtari et al., 2008; Lavajoo et al., 2011).

Uca sindensis is one of the most frequently found species among the four identified species of $U c a$ along the coast of Pakistan (Saher, 2008). These crabs form a crucial link from detritus to higher trophic level in intertidal and shallow water food web, by converting intertidal organic matter into small sized packages for many predators, both terrestrial (shore birds) and aquatic (marine invertebrates, and fishes). 
This direct conversion of detritus to biomass may be the main source of energy transfer to carnivore population (Koch et al., 2002).

Fiddler crabs are specialized as detritivores and are surface deposit feeders and therefore, the sediment type can be expected to be an important factor governing their abundance and distribution. Sediment provides two fundamental resources i.e. space and food to fiddler crabs. The particle size of the sediment substrate (Frith and Bruinmeister, 1980; Takeda and Kurihara, 1987) hardness of the substrate and the presence of structures like roots and macroalgae (Bertness and Miller, 1984) are specific features that determine the spatial distribution and zonation of the fiddler crabs. Other factors such as competition (which may be interspecific, intraspefic, or both), the type of surrounding vegetation, and elevation, also influence the density, distribution, zonation, and community structure of the intertidal crabs (Mouton and Felder, 1996).

In the present study the spatial distribution, density, handedness and size distribution of $U$. sindensis were investigated in relation with their respective habitat structure and interspecific and intraspecific competition along the coast of Pakistan.

\section{MATERIAL AND METHOD}

\section{Study sites}

The entire coast of Pakistan, which is about $990 \mathrm{~km}$ in length, consists of 320 $\mathrm{km}$ that fall in the province of Sindh and approximately $670 \mathrm{~km}$ that lie in the province of Balochistan. This coast lies in the subtropics north of the northern Arabian Sea. Karachi constitutes a coastal belt of about $100-\mathrm{km}$ long between the Indus delta on the southeast coast and Hub River on the west. The Lyari and Malir Rivers flow during rains only and drain in the Arabian Sea. These rivers also carry untreated municipal and industrial liquid and solid wastes.

Nine different sites were selected for the collection of $U c a$ crabs i.e Sandspit $\left(24^{\circ} 50^{\prime} \mathrm{N}, 66^{\circ} 56^{\prime} \mathrm{E}\right)$, Korangi creek $\left(24^{\circ} 79^{\prime} \mathrm{N}, 67^{\circ} 20^{\prime} \mathrm{E}\right)$, Ketibunder $\left(24^{\circ} 09 \mathrm{~N}\right.$, $\left.67^{\circ} 20^{\prime} \mathrm{E}\right)$, Dhabeji $\left(24^{\circ} 48^{\prime} \mathrm{N}, 67^{\circ} 29^{\prime} \mathrm{E}\right)$, Bhambore $\left(24^{\circ} 43 \mathrm{~N}, 67^{\circ} 35 \mathrm{E}\right)$, Phitti creek $\left(24^{\circ} 65^{\prime} \mathrm{N} 67^{\circ} 16^{\prime} \mathrm{E}\right)$, Sonari $\left(24^{\circ} 53^{\prime} \mathrm{N} 66^{\circ} 42^{\prime} \mathrm{E}\right)$ Sonmiani $\left(25^{\circ} 26^{\prime} \mathrm{N}, 66^{\circ} 35^{\prime} \mathrm{E}\right)$ and Bhaira $\left(25^{\circ} 29^{\prime} \mathrm{N} 66^{\circ} 33^{\prime} \mathrm{E}\right)$. All the study sites were adjacent to the mangrove vegetation except Sonari (Fig. 1). This study site is located between Cape monze and Gadani about 40 miles northwest $\left(24^{\circ} 53^{\prime} \mathrm{N}, 66^{\circ} 42^{\prime} \mathrm{E}\right)$ of Karachi. This area was once a part of Hub River but due to construction of dam it was cut off from the main river.

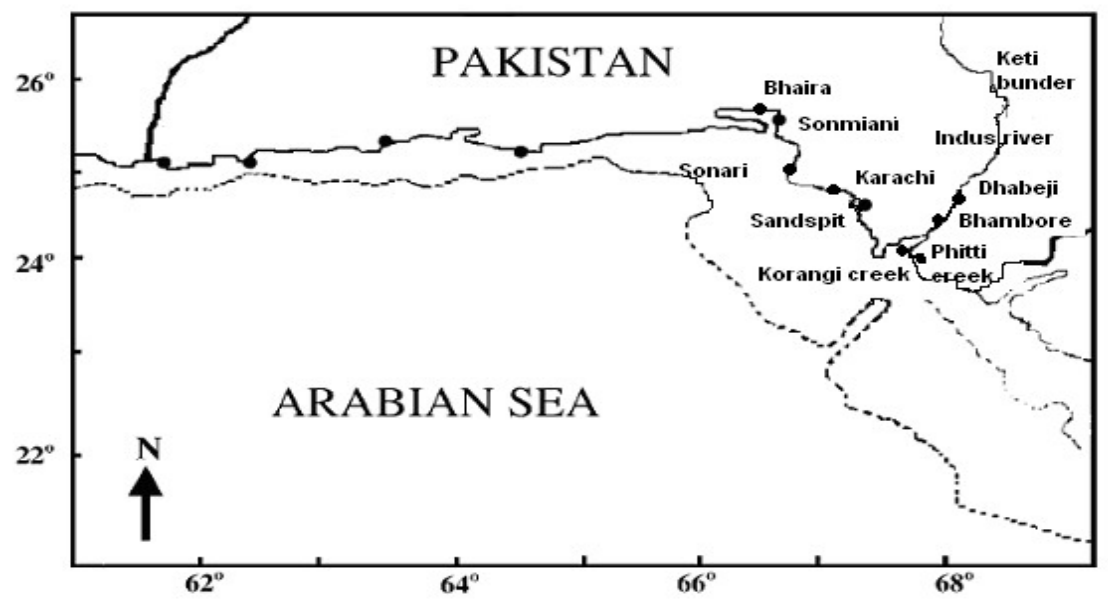

Fig. 1. Map of the study area showing the nine study sites alonng the coast of Pakistan. 
It represents mainly sea water creek extending two miles from the sea coast and is largely dominated by tidal stream with the characteristic mud flat devoid of mangrove vegetation.

Each study site was visited twice during November 2003 to March 2004 period for the collection of crabs and to determine their extant of distribution along the coast of Pakistan.

\section{Field collection}

The density or population size of fiddler crabs is estimated using a variety of methodologies due to their habit of emerging from burrows during low tide. During this study quadrate and transect method were adopted for the excavation of burrows to estimate the density of crabs. At each site two transects $(5 \mathrm{~m}$ apart) were made from low tide mark to high tide mark. On each transect, a $0.5 \mathrm{~m}$ quadrate $\left(0.25 \mathrm{~m}^{-2}\right)$ frame was placed at equidistant (5 to 10 meters apart) at three tidal levels (low tide level. mid tide level and high tide level). The numbers of levels varied and were depending on length of exposed mud flat during low tide. Crabs were hand picked within each quadrate by excavating mud up to the depth of $30 \mathrm{~cm}$ (as most of the crabs did not dig more than $30 \mathrm{~cm}$ depth), along with other crab species for later identification. To investigate the relationship of crabs with the habitat, sediment samples were collected using PVC cores (inner diameter (ID) $5.6 \mathrm{~cm}$, up to $20 \mathrm{~cm}$ deep) between two quadrats from each tidal level.

\section{Laboratory analyses}

Crabs brought to laboratory were kept in freezer at $-20{ }^{\circ} \mathrm{C}$ for sorting and identifications later on. Crabs (and the other organisms when present) were sorted, sexed and identified up to species level.

\section{Sediment characteristics}

In the laboratory, the sediment properties (percent organic matter content and grain size) were analyzed. Percent organic matter content was determined by monitoring the difference of mass loss after combustion in a muffle furnace following Saher \& Qureshi (2011). Briefly, 20-50 g of dry sediment sample was placed in a preweighed crucible, covered with a lid and combusted at $450^{\circ} \mathrm{C}$ for 3 hours. Grain size was analyzed by dry sieving methodology following Folk (1974). The sediment particle sizes expressed in phi $\Phi$ units.

\section{Statistical analyses}

Data for density distribution of $U$. sindensis and handedness were studied and were statistically analyzed using Minitab (Version 15.0). A t-test was employed under the null hypothesis that the sizes of the male were equal to the sizes of females. One way analyses of variance (ANOVA) was used to test for differences among the sites for the density of $U$. sindensis and distribution of dextral and sinistral male of $U$. sindensis. Test of significance was accepted as significant at alpha $=0.05$ for statistical analyses. Chi square test was employed to study the sex ratio and Pearson correlation coefficients were calculated to identify the relationship between $U$. sindensis distribution with sediment properties.

\section{RESULT}

\section{Sediment Properties}

The spatial variations were observed in the distribution of percent organic content and it was ranged in between 2.29 to 16.03 (Table1). Sediment percent grain size showed 75 to $90 \%$ that sediments were coarse to fine sand with the mean grain size $(\mathrm{Mz}) 1.56 \pm 0.16 \Phi$ and $1.88 \pm 0.60 \Phi$ at Sandspit and Phitti creek respectively 
(Fig. 2), whereas the mean grain size was in between 2.05 to 2.43Фphi from medium to very fine sand at all the studied sites except Bhambore, where the mean grain size was $3.15 \pm 0.24 \Phi$.

Table 1: Summary of descriptive statistics of sediment properties (percent organic, mean size of sediments, sorting coefficient), total crab density $\mathrm{m}-2$ and density of $U$. sindensis collected from the nine study sites. ( $\mathrm{N}=$ No. of observation)

\begin{tabular}{|l|c|c|c|c|c|c|}
\hline Sites & $\mathrm{N}$ & $\begin{array}{c}\text { Percent } \\
\text { organic }\end{array}$ & Mean & $\begin{array}{c}\text { Sorting } \\
\text { coefficient }\end{array}$ & $\begin{array}{c}\text { Total crab } \\
\text { density } \mathrm{m}^{-2}\end{array}$ & $\begin{array}{c}\text { Density of } U . \\
\text { sindensis } \mathrm{m}^{-2}\end{array}$ \\
\hline Bhaira & 6 & $16.09 \pm 3.54$ & $1.92 \pm 0.59$ & $1.53 \pm 0.23$ & $\begin{array}{c}37 \pm 17 \\
(18-58)\end{array}$ & $\begin{array}{c}29 \pm 2 \\
(18-40)\end{array}$ \\
\hline Sonmiani & 6 & $3.64 \pm 1.42$ & $2.09 \pm 0.34$ & $1.05 \pm 0.31$ & $\begin{array}{c}36 \pm 22 \\
(20-52)\end{array}$ & $\begin{array}{c}26 \pm 6 \\
(8-36)\end{array}$ \\
\hline Sonari & 4 & $2.63 \pm 0.74$ & $2.23 \pm 0.45$ & $1.36 \pm 0.15$ & $\begin{array}{c}62 \pm 2 \\
(48-68)\end{array}$ & $\begin{array}{c}41 \pm 1 \\
(40-48)\end{array}$ \\
\hline Sandspit & 4 & $11.26 \pm 0.69$ & $1.56 \pm 0.03$ & $0.59 \pm 0.03$ & $\begin{array}{c}40 \pm 4 \\
(40-46)\end{array}$ & $\begin{array}{c}22 \pm 6 \\
(20-34)\end{array}$ \\
\hline $\begin{array}{l}\text { Korangi } \\
\text { Creek }\end{array}$ & 4 & $3.23 \pm 0.54$ & $2.15 \pm 0.21$ & $1.27 \pm 0.21$ & $\begin{array}{c}13 \pm 4 \\
(10-16)\end{array}$ & $\begin{array}{c}9 \pm 4.2 \\
(6-12)\end{array}$ \\
\hline Phitti creek & 6 & $13.48 \pm 2.48$ & $1.88 \pm 0.60$ & $1.42 \pm 0.25$ & $\begin{array}{c}57 \pm 21 \\
(44-82)\end{array}$ & $\begin{array}{c}26 \pm 5 \\
(20-30)\end{array}$ \\
\hline Dhabeji & 6 & $11.32 \pm 4.15$ & $2.05 \pm 0.56$ & $1.60 \pm 0.13$ & $\begin{array}{c}20 \pm 11 \\
(10-40)\end{array}$ & $\begin{array}{c}16 \pm 13 \\
(8-40)\end{array}$ \\
\hline Bhambore & 6 & $2.29 \pm 0.68$ & $.15 \pm 0.24$ & $1.61 \pm 0.16$ & $\begin{array}{c}31 \pm 1 \\
(30-32)\end{array}$ & $\begin{array}{c}6 \pm 2 \\
(4-8)\end{array}$ \\
\hline Ketibunder & 8 & $10.21 \pm 0.61$ & $2.24 \pm 0.30$ & $1.64 \pm 0.16$ & $\begin{array}{c}57 \pm 21 \\
(44-82)\end{array}$ & $\begin{array}{c}20 \pm 9 \\
(12-30)\end{array}$ \\
\hline
\end{tabular}

The sediment grain size distribution showed the $40 \%$ to $90 \%$ contribution of medium to very fine sand at Bhambore, medium to fine at Korangi creek, Sonmiani and Bhaira (Fig. 2 ), whereas the percent grain size showed mixed coarse to fine sand sediments at Ketibunder, Dhabeji, Phitti Creek, Sandspit and Sonari (Fig. 2).

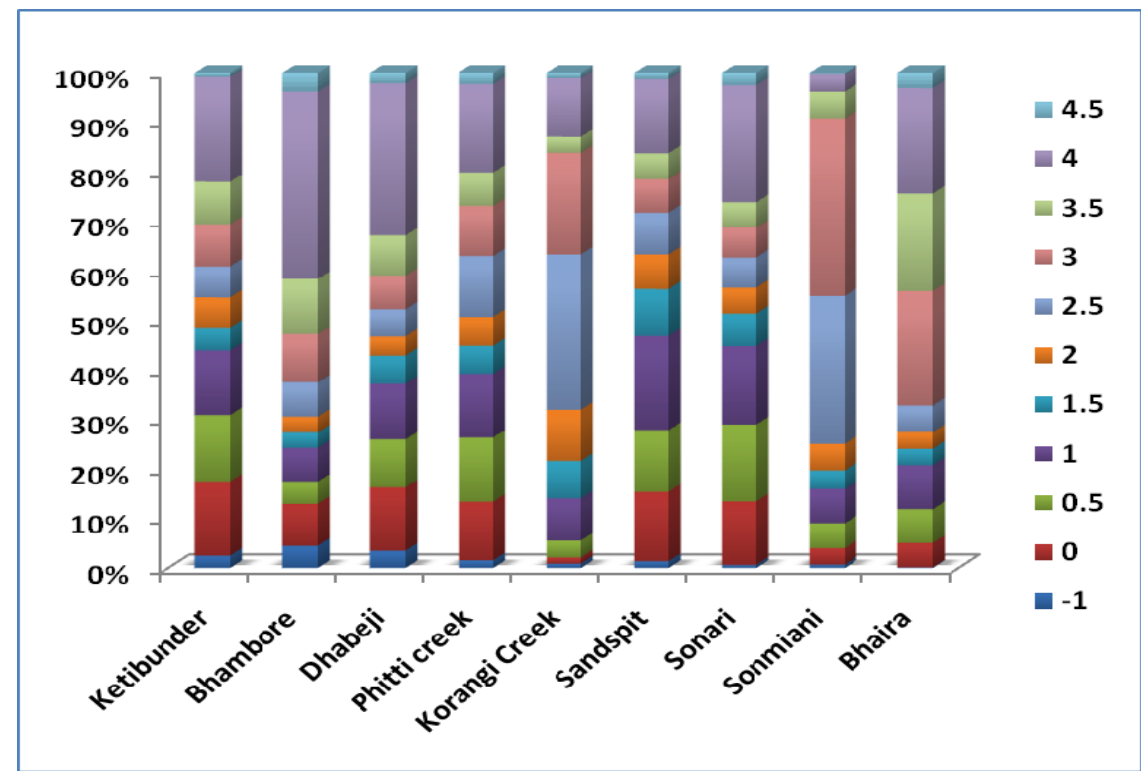

Fig. 2: Average percent contribution of grain size at nine collection sites of $U$. sindensis.

\section{Density distribution of $U$. sindensis}

$U$. sindensis was the most frequently found species along the coast of Pakistan and was mostly distributed at the Upper mid tide level to high tide level. The density of $U$. sindensis was significantly varied among all the nine sites $\left(\mathrm{F}_{8,44}=3.02, \mathrm{P}=0.03\right)$. 
The lowest mean density $\left(6 \pm 2.8 \mathrm{~m}^{2}\right)$ was observed at Bhambore and was highest $(41$ $\pm 1.4 \mathrm{~m}^{-2}$ ) at Sonari (Fig. 3, Table 1). The U. sindensis contributed from $16.2-\%$ to $44.5 \%$ percent of total crab distribution along the coast of Pakistan (Table 2). The Pearson correlation coefficient showed a positive correlation $\left(r^{2}=0.766\right)$ of density of $U$. sindensis with the percent organic content and sediment grain size.

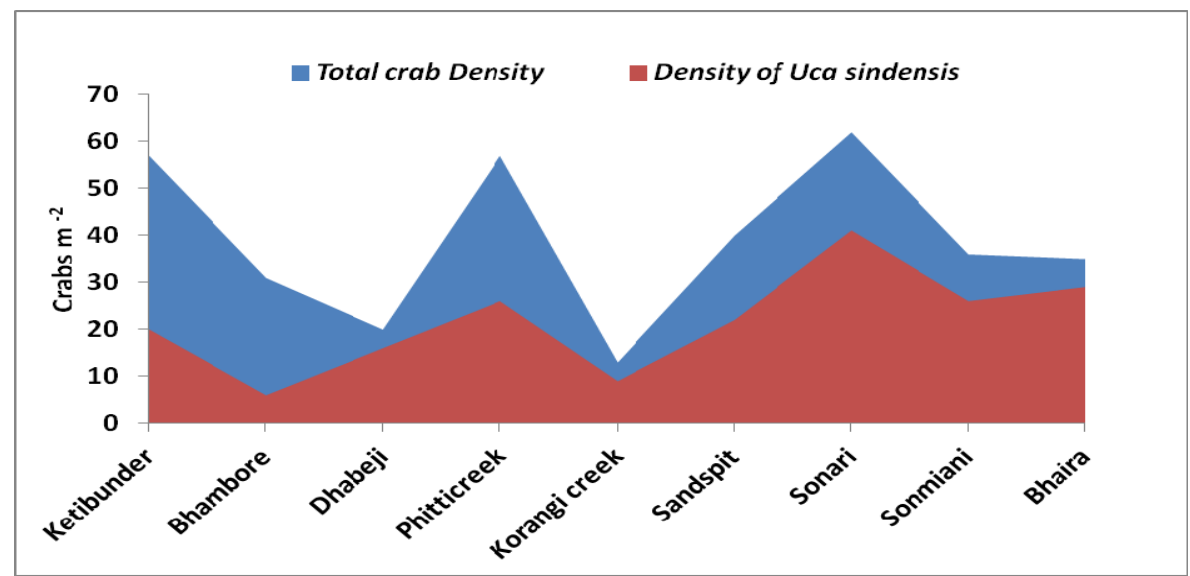

Fig. 3: Density, distribution and abundance of $U$. sindensis and total crabs at nine collection sites (data were pooled for the male and female crabs).

\section{Sex ratio and Sexual dimorphism}

The percent abundance and distribution of male and female crabs of $U$. sindensis is presented in Table 3. In U. sindensis, the percent distribution of female crabs was greater than the male crabs in Sonari, Sonmiani and Korangi creek populations. The male crabs were more abundant and showed highest percent abundance at Dhabeji, Phitti creek and Bhaira (Table 2).

Table 2: Frequency distribution of total crabs, U. sindensis, Percent sex distribution of $U$. sindensis and percent handedness of $U$. sindensis collected from nine study sites.

\begin{tabular}{|c|c|c|c|c|c|c|}
\hline & \multicolumn{2}{|c|}{ Percent density distribution } & \multicolumn{2}{c|}{ Percent Sex Ratio } & \multicolumn{2}{c|}{ Percent Handedness } \\
\hline Site & Total crab & U. Sindensis & Male & Female & Dextral & Sinistral \\
\hline Bhaira & 56.1 & 43.9 & 80 & 20 & 53 & 47 \\
\hline Sonmiani & 75 & 25 & 50 & 50 & 66 & 34 \\
\hline Sonari & 60.1 & 39.9 & 45 & 55 & 50 & 50 \\
\hline Sandspit & 60 & 40 & 55 & 45 & 46 & 54 \\
\hline Korangi creek & 59.1 & 40.9 & 45 & 55 & 44 & 56 \\
\hline Phitti creek & 68.7 & 31.3 & 80 & 20 & 52 & 48 \\
\hline Dhabeji & 55.6 & 44.4 & 82 & 18 & 62 & 38 \\
\hline Bhambore & 83.8 & 16.2 & 50 & 50 & 100 & 00 \\
\hline Keti bunder & 74.7 & 25.3 & 55 & 45 & 38 & 62 \\
\hline
\end{tabular}

The Chi-square test for difference in the sex ratios of male and female crabs showed significant difference $\left(\chi^{2}=22.4 ; \mathrm{P}=0.004\right)$ in the ratio of male and female crabs along the coast of Pakistan.

The sizes of the male and female crabs were significantly different at all studied sites. The sizes of the male crabs were significantly greater than the female crabs at all the studied sites (T-test, $\mathrm{p}<0.05)$ except Sonmiani and Dhabeji (Table 3). The mean sizes carapace width $(\mathrm{CW})$ were $10.3 \mathrm{~mm}, 12.5 \mathrm{~mm}$ and $12.7 \mathrm{~mm}$ for males and $8.8 \mathrm{~mm}$, $11 \mathrm{~mm}$ and $11.1 \mathrm{~mm}$ for females at Sonmiani, Bhambore and Dhabeji respectively (Table 2). The largest mean sizes of the male $(17.3 \mathrm{~mm} \pm 1.24)$ and the female $(14.4$ $\mathrm{mm} \pm 1.4)$ crabs were observed at Phitti creek and smallest mean sizes of the male $(8.31 \mathrm{~mm} \pm 3.19)$ and female $(6.2 \mathrm{~mm} \pm 1.25)$ crabs were observed at Bhaira. The 
mean size of the $U$. sindensis crab was positively correlated with the density of $U$. sindensis $\left(\mathrm{r}^{2}=0.666\right)$.

Table 3: The mean sizes of male and female crabs and result of T-test for $U$. sindensis collected from the nine study sites.

\begin{tabular}{|l|l|l|l|l|l|}
\hline Sites & DF & T- value & P-value & Mean \pm St.dev & \\
\hline & & & & Male $(\mathrm{mm})$ & Female $(\mathrm{mm})$ \\
\hline Bhaira & 17 & -2.36 & 0.030 & $8.31 \pm 3.19$ & $6.2 \pm 1.25$ \\
\hline Sonmiani & 2 & -1.87 & 0.278 & $10.3 \pm 0.35$ & $8.8 \pm 1.61$ \\
\hline Sonari & 17 & -2.85 & 0.000 & $9.3 \pm 0.8$ & $7.9 \pm 1.4$ \\
\hline Sandspit & 18 & -4.73 & 0.000 & $15.2 \pm 1.2$ & $13.2 \pm 0.75$ \\
\hline Korangi creek & 49 & -2.72 & 0.009 & $10.7 \pm 1.79$ & $9.49 \pm 1.81$ \\
\hline Phitti creek & 9 & -4.93 & 0.001 & $17.3 \pm 1.24$ & $14.4 \pm 1.4$ \\
\hline Dhabeji & 11 & -1.66 & 0.125 & $12.7 \pm 3.01$ & $11.1 \pm 2.19$ \\
\hline Bhambore & 2 & -1.34 & 0.408 & $12.5 \pm 7$ & $11.0 \pm 1.4$ \\
\hline Ketibunder & 26 & -2.81 & 0.009 & $11.2 \pm 1.63$ & $9.69 \pm 1.41$ \\
\hline
\end{tabular}

Fiddler crabs are notorious for their extreme sexual dimorphism. The male of $U c a$ can either have the left or the right cheliped enlarged mostly defined as dextral (right handed male) or sinistral (left handed male) male crabs. In $U$. sindensis there were all sinistral males at Bhambore and were variable at other sites. The percent distribution of dextral hypertrophied clawed male was high in Dhabeji population, and was equal to the sinistral males at Phitti creek, Sandspit and Sonari (Table 2). The one way ANOVA test did not show the significant difference from an expected 1:1 ratio $\left(\mathrm{F}_{1,17}=1.05 \mathrm{P}>0.05\right)$.

\section{DISCUSSION}

Present study reveals the importance of organic content and sediment structure for the distribution and abundance of $U$. sindensis rather than vegetation. Analysis on the organic matter quantity and substratum texture elucidated this hypothesis, since species of genus $U c a$ feed on organic particles present in sediment. Different species require and tolerate certain parameters or environmental conditions that may act as limiting factors and may be ideal for the survival of a particular species could be a limiting factor on the survival of a different species. These limiting factors act as barriers or boundaries for any species and confine them to their habitats, and even to specific levels or areas within the intertidal zone (Icely and Jones, 1978; CarmonaSuarez and Conde, 1996). In the present study it was observed that $U$. sindensis was distributed mostly on high tide level with medium to fine sand. The highest density of $U$. sindensis at Sonari as compared to other study areas with mangrove vegetation indicated the importance of substratum properties for the survival and settlement of $U$. sindensis. The density distribution of $U$. sindensis was positively correlated with percent organic indicated the preference for higher organic matter. This difference in food availability can lead to changes in substratum and population density (Hines, 1989). Fiddler crabs are generally found in areas composed of finer grained substrates with high organic content because their maxillipeds or the feeding appendages (spoon tipped setae) are specialized for filtering organic matter from the substrate (Icely and Jones, 1978; Morton and Ong Che, 1992; Ewa-Oboho, 1993, Bezzera et al. 2006). Modifications of the second maxilliped setae have been recorded in fiddler crabs as an adaptation to inhabiting different kinds of substratum (Maitland, 1990; Mounton and Felder, 1996). These modifications are important in the ecology of Uca species and can be used to explain their distribution in the mangrove forests (Jones, 1984). The 
abundance of $U$. sindensis was observed in mixed coarse to very fine sand sediments as compare to medium to fine sand areas indicated that not only the types and degrees of mouth parts specialization exhibited by species, the heterogeneity of substrate within an area can be partly determined the distribution of the $U$. sindensis along the coast of Pakistan.

The density, size distribution, community structure and zonation of the crabs are also influenced by other factors such as competition that may be interspecific (Teal, 1958), intraspecific (Crane, 1975) or both. The decrease in mean size of the adult crabs with the increase in density of $U$. sindensis and total crabs was also observed. The mean size of adult crabs in a certain population is function of environmental alterations as photoperiod, temperature, pluviosity and food availability (Campbell and Eagles, 1983). A number of brachyurans crab species also reside within a mangrove system beside fiddler crabs. These brachyuran crabs mostly belong to family grapsidae and family ocypodidae which are the key component of Indo-Pacific mangroves (Macintosh, 1984; Hartnoll et al., 2002). In many instances showing small-scale differences in habitat use with some level of habitat differentiation because of competition for limited refuge are common in soft-sediment environments (McDonald et al., 2001; Jensen et al., 2002). According to Wenner et al. (1974), the food availability can promote differences on the maximum size in which population can achieve and consequently in the size at puberty molt, because the more available is the resource, the faster is crab growth. The most typical associates of the fiddler crabs in Pakistan are other genera of Ocypodids, Macropthalminae, Dotillids and Xanthids. Particularly notable are, Uca annulipes, Uca Spp. Ilyoplax frater, Scopimera crabricauda, Opusia indica, Dotilla spp., Macrophthalmus spp. and Grapsoids spp. These all contribute importantly to the biological richness of the substrate. These species of crabs extract their food in form of organic content from the surface sediment and completely or partially rely on the same food resource for their survival thus the total density, interspecific and intraspecific competition, beside availability and the quality of the food are also the factors that can influence the growth and the mean size of the crabs (Donahue, 2004; Qureshi and Saher, 2011).

The sex ratios of fiddler crabs with more males and less females have been repeatedly observed by various authors. Skov and Hartnoll (2001), Skov et al. (2002), Johnson (2003), Litulo, (2005a; 2005b, 2005c) and Litulo (2006) are in agreement with this observation. Different reasons for the observed deviation in fiddler crabs population suggested as differential life span, temporal utilization of habitat by each sex, migration pattern, growth, and death (Wenner, 1974; Montague, 1980; Murai et al., 1983; Johnson, 2003; Litulo, 2006). Departures from the 1:1 sex ratio can be a result of sex-related capabilities to cope with environmental adversities and different spatial or temporal utilization of habitat resources.

Sexual dimorphism was also observed in the present study, the mean carapace width $(\mathrm{CW})$ of male and female crabs was significantly different for $U$. sindensis at all study sites and the male crabs had larger carapace width than female crabs. Sexual dimorphism has been observed with males larger than females in other species of Uca (Johnson, 2003; Mantelatto et al., 2003; Litulo, 2005b; 2006). Male crabs attain large size for better competition by winning more interspecific flight and chances of obtaining female crabs (Henmi, 2000; Lutilo, 2005a). In addition, as females spend their energetic demands more on the gonadal or reproductive development than male, that may result in reduced somatic growth in female in comparison to male crabs 
(Lopez Greeco et al., 2000; Mantelatto et al., 2003 Litulo, 2005b; Lavajoo et al. 2011).

Fiddler crabs are well known for their outstanding sexual dimorphism (Crane, 1975; Mariapapan et al., 2001). In U. sindensis handedness was variable for all the studied populations except Bhambore where all males were left handed. The relative frequencies of left and right handed hypertrophied chelipede of male crabs have been observed to vary in between different populations (Vernberg and Costlow, 1966). Results of our study indicated that the proportion of dextral and sinistral males did not significantly different from 1:1 ratio. However, generally, the right or left handedness of enlarged chelipede in male crabs occurs in equal numbers and the random differentiation in handedness could be hormonally induced (Bezerra et al., 2007). In addition, the ratios of right and left handed males in different populations of $U c a$ were studied and reported equal proportion of right and left handed males (Takeda and Murai, 1993; Lavajoo et al., 2011). The presence of either left or right was purely occasional and not apparently related with any bitic or abiotic factors.

\section{CONCLUSION}

The result of this study reveals the importance of sediment properties (percent organic and grain size) in the distribution and abundance of $U$. sindensis along the coast of Pakistan. Not only the sediment properties the presence or absence of other associated crab species, but also appeared to affect the density and sizes of the $U$. sindensis crab along the coast of Pakistan.

\section{ACKNOWLEDGEMENT}

This work was funded by the Pakistan Science Foundation project PSF/Res/S$\mathrm{KU} /$ Envr (51) grant to NAQ and is gratefully acknowledged.

\section{REFERENCES}

Barnes, R. S. K. (2010). A review of the sentinel and allied crab (Dacapoda: Brachyura: Macrophthalminae with particular reference to genus Macrophthalmus. Raffles Bulletin of Zoology, 58: 31-49.

Bertness, M. D. and Miller, T. (1984). The distribution and dynamics of Uca pugnax (Smith) burrows in a New England salt marsh. Journal of Experimental Marine Biology and Ecology 83: 211-237.

Bezerra, L.E.A., Dias, C. B. Santana G. X. and Cascon H. M. (2006). Spatial distribution of fiddler crabs (genus $U c a$ ) in a tropical mangrove of northeast Brazil. Scientia Marina, 70:759-766.

Bezerra, L.E.A., Santana G. X. and Cascon H. M. (2007). Population and reproductive biology of of the fiddler crab Uca thyeri Rathbun 1900 (Crustacea:Ocypodidae) in a tropical mangrove of northeast Brazil. Acta Oecologica, 31:251-258.

Campbell, A. and Eagles, M. D. (1983). Size at maturity and fecundity of rock crabs, Cancer irroratus, from the Bay of Fundy and southwestern Nova Scotia. Fisheries Bulletin 81: 357-362.

Carmona-Suarez, C. A. and Conde, J. E. (1996). Littoral Brachyuran crabs (Crustacea: Decapoda) from Falcon, Venezuela, with biogeographical and ecological remarks. Review of Brasilian Biology 56: 725-747. 
César, I. I., L. C. Armendáriz, and R. V. Becerra, (2005). Bioecology of the fiddler crab Uca uruguayensis and the burrowing crab Chasmagnathus granulatus (Decapoda, Brachyura) in the Refugio de Vida Silvestre Bahía Samborombón, Argentina. Hydrobiologia 545: 237-248.

Colpo, K. D. and M. L. Negreiros-Fransozo, (2004). Comparison of the population structure of the fiddler crab Uca vocator (Herbst, 1804) from three subtropical mangrove forests. Scientia Marina 68: 139-146.

Costa, T. M. and M. L. Negreiros-Fransozo, (2002). Population biology of Uca thayeri Rathbun, 1900 (Brachyura, Ocypodidae) in a subtropical South American mangrove area: Results from transect and catch-per-unit-effort techniques. Crustaceana 75: 1201-1218.

Costa, T. M. and Negreiros-Fransozo M. L. (2001). Morphological adaptation of the second maxilliped in semi-terrestrial crabs of the genus Uca Leach, 1814 (Decapoda, Ocypodidae) from a subtropical Brazilian mangrove. Nauplius 9: 123-131.

Crane, J. (1975). Fiddler Crabs of the World: Ocypodidae: Genus Uca Princeton, NJ: Princeton University Press.

Donahue, M. J. (2004). Size-dependent competition in a gregarious porcelain crab Petrolisthes cinctipes (Anomura: Porcellanidae). Marine Ecological Progress Series 267: 219-231.

Ewa-Oboho, I. O., (1993). Substratum preference of the tropical estuarine crabs, Uca tangeri Eydoux (Ocypodidae) and Ocypode cursor Linne (Ocypodidae). Hydrobiologia 271: 119-127.

Frith, D. W. and S. L. Brunenmeister, (1980). Ecological and population studies of fiddler crabs (Ocypodidae, genus Uca) on a mangrove shore of Phuket Island, western peninsular Thailand. Crustaceana 39: 157-184.

Hartnoll, R. G., (1988). Evolution, systematics, and geographical distribution. In: W.W Burggren and B.R McMahon, Editors, Biology of the Land Crabs, Cambridge University Press, Cambridge., pp. 6-54.

Hartnoll, R. G., Cannicci, S., Emmerson, W. D., Fratini, S., Macia, A., Mgaya, Y., Porri, F., Ruwa, R. K., Shunula, J. P., Skov, M. W. and M. Vannini, (2002). Geographic trends in mangrove crab abundance in East Africa. Wetland Ecology Management. 10: 203-213.

Henmi, Y., (2000). Comparisons of life history traits among populations of the ocypodid crab Macrophthalmus japonicus in habitats with contrasting food availability, Crustacean Research 29: 109-120.

Icely, J. D. and Jones D. A. (1978). Factors affecting the distribution of the genus Uca (Crustacea:Ocypodidae) on East African shore. Estuarine Coastal Marine Sciences 6: 315-325.

Jensen, G. C., McDonald, P. S. and Armstrong, D. A., (2002). East meets west: competitive interactions between green crab Carcinus maenas, and native and introduced shore crab Hemigrapsus spp. Marine Ecology Progress Series 225: 251-262.

Johnson, P. T. J., (2003). Biased sex ratios in fiddler crabs (Brachyura, Ocypodidae): A review and evaluation of the influence of sampling method, size class, and sex-specific mortality. Crustaceana 76: 559-580.

Jones, D. A. (1984). Crabs of the mangal ecosystem. In Hydrobiology of the mangal, F. D. Por and I. Dor (Eds.), W. Junk Publishers, Boston. 89-109 pp. 
Koch, V., M. Wolff and K. Diele, (2005). Comparative population dynamics of four fiddler crabs (Ocypodidae, genus $U c a$ ) from a North Brazilian mangrove ecosystem. Marine Ecology Progress Series 291: 177-188.

Lavajoo F., Kamrani E. and Sajjadi M. (2011). Distribution, population and reproductive biology of the Fiddler crab U. sindensis (Crustacea: Ocypodidae) in a subtropical mangrove of Pohl area.Journal of the Persian Gulf 2: 9-16

Litulo, C. (2005a): Population biology of the fiddler crab Uca annulipes (Brachyura: Ocypodidae) in a tropical East African mangrove (Mozambique). Estuarine, Coastal and Shelf Science 62: 283-290.

Litulo, C. (2005b): Population structure and reproductive biology of the fiddler crab Uca inversa (Hoffman, 1874) (Brachyura: Ocypodidae). Acta Oecologica 27: $135-141$.

Litulo, C., (2005c): Population structure and reproductive biology of the fiddler crab Uca urvillei (Brachyura: Ocypodidae) in Maputo Bay (south Mozambique). Journal of Natural History 39: 2307-2318.

Litulo, C., (2006): Population and reproductive biology of the fiddler crab Uca chlorophthalmus (Brachyura: Ocypodidae) from Inhaca Island, southern Mozambique. J. Marine Biolog. Assoc. United Kingdom, 86: 737-742.

Lopez Greco, L. S., Hernandez, J. E., Bolanos, J., Rodriguez, E. M. \& G. Hernandez (2000): Population features of Microphrys bicornutus Latreille, 1825 (Brachyura, Majidae) from Isla Margarita, Venezuela. Hydrobiologia 439: 151159.

Macintosh, D. J. (1984): Ecology and productivity of Malaysian mangrove crab population (Decapoda: Brachyura). In: Proc. As. Symp. Mangr. Env. Res. Manag., UNESCO (Paris) 20 (1984), pp. 354-377.

Maitland, D. P. (1990). Feeding and mouthpart morphology in the semaphore crab Heloecius cordiformis (Decapoda: Brachyura: Ocypodidae). Marine Biology 105: 287-296.

Mantelatto, F. L. M., F. C. R. Faria and Garcia R. B. (2003): Biological aspects of Mithraculus forceps (Brachyura: Mithracidae) from Anchieta Island, Ubatuba, Brazil, Journal of Marine Biological Association UK 83: 789-791.

Mariappan, P., Balasundaran C. and Scmitz, B. (2000): Decapod crustacean chelipeds: an overview, Journal of Biological Science 25: 301-313.

McDonald, P. S., Jensen G. C. and Armstrong D. A. (2001): The competitive and predatory impacts of the non indigenous crab Carcinus maenas (L.) on early benthic phase Dungeness crab Cancer magister Dana. Journal of Experimental Marine Biology and Ecology 258: 38-54.

Montague, C. L. (1980): A natural history of temperate western Atlantic fiddler crabs (genus Uca) with reference to their impact on the salt marsh. Contributions in Marine Science 23: 25-55.

Morton, B. and Ong Che R. G. (1992): Morphology and sediment dynamics of the sand beach at Hoi Ha Wan. In: The Marine Flora and Fauna of Hong Kong and Southern China III, B. Morton (Ed.) Hong Kong University Press, Hong Kong. Pp. 787-800.

Mouton, E. C., Jr. and Felder D. L. (1995): Reproduction of the fiddler crabs Uca longisignalis and Uca spinicarpa in a Gulf of Mexico salt marsh. Estuaries 18: 469-481.

Mouton, E. C., Jr., and Felder D. L. (1996): Burrow distributions and population estimates for the fiddler crabs Uca spinicarpa and Uca longisignalis in a Gulf of Mexico salt marsh. Estuaries 19(1): 51-61. 
Murai, M., S. Goshima, and Y. Nakasone, (1982): Some behavioral characteristics related to food supply and soil texture of burrowing habitats observed on Uca vocans vocans and Uca lactea perplexa. Marine Biology 66: 191-197.

Nobbs, M. and McGuinness K. A. (1999): Developing methods for quantifying the apparent abundance of fiddler crabs (Ocypodidae: $U c a$ ) in mangrove habitats. Australian Journal of Ecology, 24: 43-49.

Nobbs, M., (2003): Effects of vegetation differ among three species of fiddler crabs (Uca spp.). Journal of Experimental Marine Biology and Ecology 284: 41-50.

Qureshi N. A. \& Saher N. U. (2011): Relative growth and morphological sexual maturity of Macrophthalmus (venitus ) dentipes Lucas, in Guerin-Meneville, 1836from two mangrove areas of Karachi Coast. Biharean Biologist 5: 56-62.

Ribeiro, P. D., Iribarne O. O. and Daleo P., (2005): The relative importance of substratum characteristics and recruitment in determining the spatial distribution of the fiddler crab Uca uruguayensis Nobili. Journal of Experimental Marine Biology and Ecology 314: 99-111.

Saher N. U. (2008): Population dynamics and biology of fiddler crabs in the mangrove areas of Karachi coast. Ph. D thesis, University of Karachi, Pakistan.

Saher, N. U. \& Qureshi, N. A. (2011): Density, distribution and population structure of Opusia indica (Ocypodoidae: Camptandriidae) in a coastal angrove creek in Pakistan. Biologia 66: 181-186.

Skov, M.W. and Hartnoll, R. G. (2001): Comparative suitability of binocular observation, burrow counting and excavation for the quantification of the mangrove fiddler crab Uca annulipes (H. Milne Edwards). Hydrobiologia 449: 201-212.

Skov. M.W., Vannini, M., Shunnula, J. P., Hartnoll, R.G. and Cannicii S., (2002): Quantifying the density of mangrove crabs: Ocypodidae and Grapsidae. Marine Biology 141: 725-732.

Takeda, S. \& Kurihara Y. (1987): The effects of burrowing of Helice tridens (De Haan) on the soil of a salt marsh habitat. Journal of Experimental Marine Biology and Ecology 113: 79-89.

Takeda, S. \& Murai M. (2003): Morphological and behavioural adaptations to the rocky substrate by the fiddler crab Uca panamensis (Stimpson, 1859): Preference for feeding substratum and feeding mechanism. Journal of Experimental Marine Biology and Ecology 287: 179-191.

Teal, J. M. (1958): Distribution of fiddler crabs in Georgia salt marshes. Ecology 39: 185-193.

Vernberg, F. J. and Costlow, J. D. Jr. (1966): Handedness in fiddler crabs. Crustaceana 11:61-64.

Wenner, A. M. (1972): Sex-ratio as a function of size in marine Crustacea. American Naturalist 106: 321-350. 